\title{
Kualitas Pelayanan Kesehatan Peserta Badan Penyelenggara Jaminan Sosial Kesehatan di Pusat Kesehatan Masyarakat Tanasitolo Kabupaten Wajo
}

\author{
Ruslang $^{1^{*}}$, Amir Imbaruddin $^{2}$, Halim $^{3}$ \\ 1*. Universitas Puangrimaggallatung Sengkang, Jl. Sultan Hasannudin No.27, Kabupaten Wajo, Indonesia, 90918 \\ 2. STIA LAN Makassar, Jl. A. P. Pettarani No.61, Kota Makassar, Indonesia, 90231 \\ 3. STIA LAN Makassar, Jl. A. P. Pettarani No.61, Kota Makassar, Indonesia, 90231 \\ "e-mail : ruslangdalfint@yahoo.co.id/082190612867
}

(Received : 13-03-2019; Reviewed : 20-03-2019; Accepted : 12-04-2019)

\begin{abstract}
The problem analysed in the study was about service quality of social security administrator at Tanasitolo community health center of Wajo regency. The objective of the study was understand the service quality of of social security administrator at Tanasitolo community health center of Wajo regency. The study applied a quantitative approach with descriptive research design. Population of the study were of social security administrator who had received health services at Tanasitolo community health center of Wajo regency, which totaled 10.838 visits. Using non-probability sampling technique of purposive sampling, 99 patients were selected as respondents of the study. The results of the study showed that the interaction quality included the attitudes of officers, the behavior of officers and the expertise of officers scored 4.22 or categorized as quality. The physical environment quality included room conditions, room design and social factors scored of 4.04 or categorized as having a quality The outcome quality including impression scored 4.22 or good category.
\end{abstract}

Keywords: Social Security Administrator, Quality, Interaction, Physical Environment, Outcome

\begin{abstract}
Abstrak
Permasalahan dalam penelitian ini adalah Kualitas Pelayanan Kesehatan Peserta Badan Penyelenggara Jaminan Sosial Kesehatan di Pusat Kesehatan Masyarakat Tanasitolo Kabupaten Wajo. Penelitian ini bertujuan untuk mengetahui Kualitas Pelayanan Kesehatan Peserta Badan Penyelenggara Jaminan Sosial Kesehatan di Pusat Kesehatan Masyarakat Tanasitolo Kabupaten Wajo. Metode yang digunakan dalam penelitian adalah pendekatan kuantitatif dengan desain penelitian deskriptif. Populasi dalam penelitian ini adalah peserta Badan Penyelenggara Jaminan Sosial Kesehatan yang telah mendapatkan pelayanan kesehatan di Pusat Kesehatan Masyarakat Tanasitolo Kabupaten Wajo yang berjumlah 10.838 kunjungan. Penetapan sampel dengan menggunakan metode non-probability sampling dengan teknik purposive sampling, sehingga diperoleh sampel sebanyak 99 orang. Hasil penelitian ini menunjukkan bahwa komponen kualitas interaksi (interaction quality) yang mencakup sikap petugas, perilaku petugas dan keahlian petugas dengan nilai ratarata 4,22 (kategori berkualitas). Komponen kualitas lingkungan fisik (physical environment quality) yang mencakup kondisi ruangan, desain ruangan dan faktor sosial dengan nilai rata-rata 4,04 (kategori berkualitas). Komponen kualitas hasil (outcome quality) yang mencakup kesan dengan nilai rata-rata 4,22 (kategori baik).
\end{abstract}

Kata Kunci : Badan Penyelenggara Jaminan Sosial, Kualitas, Interaksi, Lingkungan Fisik, Hasil 


\section{Pendahuluan}

Bidang kesehatan merupakan disiplin yang mempengaruhi perkembangan dari ilmu kesejahteraan sosial. Bahkan bidang kesehatan dianggap sebagai salah satu indikator berkembangnya kesejahteraan masyarakat di suatu wilayah geografis tertentu. (Riyadi, R. 2015) Dalam Undang-Undang No.36 Tahun 2009 tentang Kesehatan ditegaskan bahwa setiap orang mempunyai hak yang sama dalam memperoleh akses atas sumber daya di bidang kesehatan dan memperoleh pelayanan kesehatan yang aman, berkualitas, dan terjangkau. Sebaliknya, setiap orang juga mempunyai kewajiban turut serta dalam program jaminan kesehatan sosial. (Republik Indonesia. Undang-Undang No.36 Tahun 2009). Untuk mengatasi hal itu, pada tahun 2004, dikeluarkan Undang-Undang No. 40 tentang Sistem Jaminan Sosial Nasional (SJSN). Undang-Undang No. 40 Tahun 2004 ini mengamanatkan bahwa jaminan sosial wajib bagi seluruh penduduk termasuk Jaminan Kesehatan Nasional (JKN) melalui suatu Badan Penyelenggara Jaminan Sosial (BPJS). Undang-Undang No. 24 Tahun 2011 tentang BPJS juga menetapkan, Jaminan Kesehatan Nasional akan diselenggarakan oleh BPJS, yang terdiri dari BPJS Kesehatan dan BPJS Ketenagakerjaan. (Republik Indonesia. Undang-Undang No. 40 Tahun 2004)

Untuk mewujudkan Universal Health Coverage pada 1 Januari 2019, diperlukan dukungan dari seluruh Pemerintah Daerah (Pemda) untuk mengintegrasikan Jaminan Kesehatan Daerah (Jamkesda) masing-masing wilayahnya ke program Jaminan Kesehatan Nasional-Kartu Indonesia Sehat (JKN-KIS). Dengan adanya Jaminan Kesehatan Nasional yang dijalankan oleh BPJS Kesehatan, diharapkan seluruh masyarakat terutama masyarakat miskin yang selama ini mengalami kesulitan dalam mendapatkan pelayanan kesehatan yang layak dan berkualitas karena keterbatasan finansial. (BPJS Kesehatan. 470 Kabupaten/Kota telah terintegrasi antara Jamkesda ke JKN-KIS, Diakses pada tanggal 23 November 2017, jam 21.23 WITA, www.bpjs-kesehatan.go.id)

Namun faktanya masih banyak masyarakat yang belum mengetahui Jaminan Kesehatan Nasional itu sendiri, kemudahan pengobatan dengan menggunakan Jaminan Kesehatan Nasional pun belum sepenuhnya berhasil, karena panjangnya birokrasi dan sarana-prasarana pendukung program Jaminan Kesehatan Nasional tersebut. Selain itu jumlah penduduk juga menjadi faktor penghambat pemenuhan kebutuhan kesehatan. Program Jaminan Kesehatan Nasional oleh BPJS Kesehatan akan berjalan maksimal jika diiringi kualitas pelayanan kesehatan yang baik oleh penyedia jasa kesehatan. Peningkatan kualitas pelayanan kesehatan seperti BPJS akan berhasil dengan kontribusi masyarakat. Kesadaran masyarakat tentang kualitas pelayanan kesehatan tentunya dipengaruhi tingkat pengetahuan masyarakat itu sendiri. Hal ini dibuktikan sejak BPJS Kesehatan telah menjangkau untuk semua kalangan masyarakat, berbagai kritik saran ditujukan kepada pelayanan kesehatan agar kualitas pelayanan semakin meningkat. Berdasarkan data BPJS Kesehatan, tahun 2017 jumlah peserta BPJS Kesehatan di Indonesia mencapai 183.579.086 jiwa yang terdiri dari PBI APBN sebanyak 92.211.728 jiwa, PBI APBD sebanyak 19.381.926 jiwa, PNS sebanyak 13.719.929 jiwa, TNI sebanyak 1.570.636 jiwa, POLRI sebanyak 1.241.706 jiwa, BUMN sebanyak 1.420.297 jiwa, BUMD sebanyak 172.890 jiwa, Swasta sebanyak 24.853.778 jiwa, Pekerja Mandiri sebanyak 24.041.754 jiwa dan Bukan Pekerja sebanyak 4.964.442 jiwa. (http://bpjs-kesehatan.go.id/bpjs/index.php/jumlahPeserta, diakses pada tanggal 25 November 2017, jam 19.59 WITA).

Berdasarkan infomasi yang diperoleh dari pengelola BPJS Kesehatan Puskesmas Tanasitolo, jumlah kepesertaan BPJS Kesehatan wilayah kerja Puskesmas Tanasitolo Kabupaten Wajo Tahun 2017 mencapai 13.874 jiwa. Jumlah kunjungan rawat jalan peserta BPJS Kesehatan di Puskesmas Tanasitolo Tahun 2017 yang mendapatkan pelayanan tidak pernah berada di bawah 500 jumlah kunjungan per-bulannya. Puskesmas sebagai organisasi pelayanan publik tidak terlepas dari sorotan dan penilaian masyarakat penggunanya. Pelayanan yang diberikan masih menuai keluhan dari masyarakat, baik berupa pelayanan medis maupun sarana dan prasarana. Penelitian yang dilakukan oleh Reizky Riyadi pada tahun 2015 mengenai Mutu Pelayanan Kesehatan Peserta Jaminan Kesehatan Nasional di Puskesmas Kecamatan Kembangan Jakarta Barat membuktikan bahwa mutu atau kualitas pelayanan yang diberikan oleh Puskesmas Kecamatan Kembangan secara umum tergolong baik dengan nilai rata-rata 83,25\%, tetapi masih terdapat dimensi pelayanan kesehatan yang belum berjalan secara maksimal dirasakan oleh peserta Jaminan Kesehatan Nasional dibuktikan dengan nilai dibawah $80 \%$. Beberapa yang ditemukan di Puskesmas Tanasitolo terkait dengan dimensi kualitas pelayanan. Dari sudut pandang manajerial, Hierarchial Service Quality Model sangat berguna untuk menilai kualitas pelayanan di berbagai tingkat untuk mendeteksi adanya masalah dalam menyampaikan kualitas pelayanan, kualitas hasil, atau lingkungan fisiknya. Berdasarkan observasi yang telah dilakukan di Puskesmas Tanasitolo ternyata masyarakat masih mengeluhkan kecepatan pelayanan di Puskesmas Tanasitolo. Masalah ini terkait dengan dimensi kualitas pelayanan yang dikembangkan oleh Brady and Cronin. Dari sudut pandang manajerial, wujud kualitas interaksi yang diperkenalkan oleh Puskesmas Tanasitolo mencakup sikap petugas, perilaku petugas dan keahlian petugas dari pihak yang memberikan layanan, khususnya pelayanan kesehatan rawat jalan peserta BPJS Kesehatan.

Wujud kualitas lingkungan fisik perlu ditunjukkan di dalam memenuhi pelayanan berkualitas agar setiap pasien merasakan bentuk layanan yang diberikan. Layanan tersebut berupa kondisi fisik dari puskesmas seperti kondisi ruangan dan desain ruangan serta faktor sosial dalam memenuhi kepuasan pasien. Wujud kualitas hasil merupakan kesan layanan yang diterima oleh pasien tidak menimbulkan adanya kritikan dan ketidak-puasan atas bentuk pelayanan yang diberikan untuk mewujudkan zero complaint. Ketiga wujud ini perlu dipertimbangkan oleh Puskesmas Tanasitolo 
agar tidak mengalami penurunan kunjungan. Oleh karena itu, penelitian ini akan menganalisis apa saja dimensi kualitas pelayanan kesehatan peserta BPJS kesehatan di Puskesmas Tanasitolo Kabupaten Wajo.

\section{Metode}

Menggunakan pendekatan kuantitatif dengan desain penelitian deskriptif di Puskesmas Tanasitolo Kabupaten Wajo. Hasil penelitian ini akan dideskripsikan untuk menjelaskan variabel yang diteliti yaitu penelitian tentang kualitas pelayanan kesehatan peserta BPJS Kesehatan. Dengan teknik pengumpulan data melalui penyebaran kuesioner, melakukan wawancara terstruktur, melakukan observasi serta melakukan telaah dokumen.

Populasi dalam penelitian ini adalah peserta BPJS kesehatan yang telah mendapatkan pelayanan kesehatan di Puskesmas Tanasitolo Kabupaten Wajo yang berjumlah 10.838 kunjungan. Penetapan sampel dengan menggunakan metode nonprobability sampling dengan teknik purposive sampling, sehingga diperoleh sampel sebanyak 99 orang dari 10.838 populasi lansia menggunakan rumus Slovin. Secara kuantitatif, deskripsi data didasarkan pada perhitungan ratarata dari skor setiap alternatif jawaban angket, sehingga diperoleh skor rata-rata jawaban responden untuk menentukan nilai mutu/kualitas dari masing-masing variabel dengan rentang penafsiran sebagai berikut: Sangat Berkualitas (nilai = 5), Berkualitas (nilai $=4-<5$ ), Cukup Berkualitas (nilai $=3-<4$ ), Tidak Berkualitas (nilai $=2-<3$ ), Sangat Tidak Berkualitas (nilai $=1-<2$ ).

\section{Hasil}

Tabel 1. Karakteristik Responden

\begin{tabular}{|c|c|c|}
\hline Karakteristik & Frekuensi & Persentase (\%) \\
\hline \multicolumn{3}{|l|}{ Umur } \\
\hline $17-25$ & 10 & 10,1 \\
\hline $26-45$ & 50 & 50,5 \\
\hline $46-65$ & 29 & 29,3 \\
\hline$>65$ & 10 & 10,1 \\
\hline \multicolumn{3}{|l|}{ Jenis Kelamin } \\
\hline Laki-laki & 23 & 23,2 \\
\hline Perempuan & 76 & 76,8 \\
\hline \multicolumn{3}{|l|}{ Pendidikan } \\
\hline Tidak Sekolah & 13 & 13,1 \\
\hline SD & 41 & 41,4 \\
\hline SMP & 13 & 13,1 \\
\hline SMA & 15 & 15,2 \\
\hline Sarjana & 16 & 16,2 \\
\hline Pascasarjana & 1 & 1,0 \\
\hline \multicolumn{3}{|l|}{ Pekerjaan } \\
\hline PNS & 2 & 2,0 \\
\hline Pegawai Swasta & 5 & 5,1 \\
\hline Pegawai Honor/Kontrak & 2 & 2,0 \\
\hline Wiraswasta & 23 & 23,2 \\
\hline Ibu Rumah Tangga & 56 & 56,6 \\
\hline Pekerjaan Lainnya & 11 & 11,1 \\
\hline \multicolumn{3}{|l|}{ Jumlah Kunjungan } \\
\hline $2-4$ kali & 56 & 56,6 \\
\hline $5-7$ kali & 17 & 17,2 \\
\hline $8-10$ kali & 10 & 10,1 \\
\hline Lebih dari 10 kali & 16 & 16,2 \\
\hline
\end{tabular}

Berdasarkan tabel di atas menunjukkan bahwa sebagian umur responden antara 26-45 tahun sebanyak 50,5\%. Dari 99 responden, diperoleh data bahwa umur responden yang terendah adalah 18 tahun dan umur responden yang tertinggi adalah 76 tahun dengan umur rata-rata responden adalah 43,6 tahun. Responden terbanyak adalah berjenis kelamin perempuan dengan persentase sebesar 76,8\%. Hasil tersebut dapat didukung dengan hasil telaah dokumen profil Puskesmas Tanasitolo menunjukkan bahwa jumlah penduduk di wilayah kerja sebanyak 25.965 jiwa yang terdiri dari laki-laki sebanyak 12.302 jiwa dan perempuan sebanyak 13.663 jiwa. Berdasarkan uraian di atas dapat disimpulkan bahwa pada umumnya memiliki kesempatan terbanyak menggunakan fasilitas kesehatan adalah perempuan. Sebagian 
besar tingkat pendidikan responden adalah SD sebesar 41,4\%, sehingga dapat dikategorikan bahwa tingkat pendidikan responden umumnya masih rendah. Sebagian besar pekerjaan responden adalah Ibu rumah tangga sebanyak $56,6 \%$. Umumnya responden telah berkunjung ke puskesmas dalam satu tahun terakhir 2-4 kali sebanyak 56,6\%.

\section{Deskripsi dan Analisis Data}

\section{Kualitas Interaksi (Interaction Quality)}

Kualitas interaksi (interaction quality) adalah interaksi personal selama pemberian pelayanan kesehatan rawat jalan di Puskesmas Tanasitolo yang meliputi: sikap petugas, perilaku petugas, dan keahlian petugas.

\section{a. Sikap Petugas}

Sikap petugas adalah pilihan tindakan pemberi pelayanan dalam melayani pasien rawat jalan peserta BPJS Kesehatan. Dengan demikian, puskesmas diharapkan memiliki petugas yang mampu memilih tindakan yang tepat kepada pasien sesuai tingkat kegawat-daruratan. Berdasarkan hasil penilaian diperoleh rata-rata jawaban responden adalah 4,25 dengan jumlah persentase jawaban sangat setuju dan setuju sebanyak $100 \%$. Hal ini menunjukkan bahwa petugas yang menangani peduli dengan kondisi kesehatan responden. Aspek ketanggapan petugas dinilai responden dengan rerata 4,18 dengan jumlah persentase jawaban sangat setuju dan setuju sebanyak $100 \%$. Hal ini menunjukkan bahwa petugas tanggap dalam mengambil tindakan sesuai dengan keadaaan responden. Rerata jawaban responden mengenai sikap petugas mencari informasi adalah 4,19 dengan jumlah persentase jawaban sangat setuju dan setuju sebanyak $98 \%$. Hal ini menunjukkan bahwa petugas bersedia mencarikan informasi yang responden butuhkan.

\section{b. Perilaku Petugas}

Perilaku petugas adalah tindakan petugas yang tanggap dalam memberikan pelayanan kepada pasien rawat jalan peserta BPJS Kesehatan. Dengan demikian puskesmas diharapkan memiliki petugas dengan dengan kemampuan komunikasi yang baik dalam memberikan pelayanan. Berdasarkan hasil penilaian diperoleh rata-rata jawaban responden adalah 4,17 dengan jumlah persentase jawaban sangat setuju dan setuju sebanyak 97\%. Hal ini menunjukkan bahwa petugas selalu merespon kebutuhan responden dengan cepat. Tanggapan responden tentang petugas menjawab pertanyaan dan keluhan responden dengan sabar adalah 4,15 dengan jumlah persentase jawaban sangat setuju dan setuju sebanyak 97\%. Hal ini menunjukkan bahwa petugas menjawab pertanyaan dan keluhan responden dengan sabar. Tanggapan responden tentang petugas segera memberikan bantuan saat responden adalah 4,19 dengan jumlah persentase jawaban sangat setuju dan setuju sebanyak 100\%. Hal ini menunjukkan bahwa petugas segera memberikan bantuan saat responden membutuhkan.

\section{c. Keahlian Petugas}

Keahlian petugas adalah kemahiran, kompetensi dan profesionalitas petugas kesehatan di Puskesmas Tanasitolo dalam memberikan pelayanan kepada pasien rawat jalan peserta BPJS Kesehatan. Dengan demikian, puskesmas diharapkan memiliki petugas dengan kemampuan dan tingkat pengetahuan serta pemahaman memberikan pelayanan yang terpercaya dan tidak menimbulkan kesalahan. Tanggapan responden tentang petugas yang menangani adalah petugas yang ahli dalam bidangnya adalah 4,27 dengan jumlah persentase jawaban sangat setuju dan setuju sebanyak 97\%. Hal ini menunjukkan bahwa petugas yang menangani adalah petugas yang ahli dalam bidangnya. Petugas yang menangani tidak pernah melakukan kesalahan dalam memberikan pelayanan adalah 4,25 dengan jumlah persentase jawaban sangat setuju dan setuju sebanyak $100 \%$. Hal ini menunjukkan bahwa petugas yang menangani tidak pernah melakukan kesalahan dalam memberikan pelayanan. Petugas memberikan penjelasan dengan bahasa yang mudah dan dapat dimengerti adalah 4,30 dengan jumlah persentase jawaban sangat setuju dan setuju sebanyak 99\%. Hal ini menunjukkan bahwa petugas memberikan penjelasan dengan bahasa yang mudah dan dapat dimengerti.

\section{d. Kesimpulan Komponen Kualitas Interaksi (Interaction Quality)}

Tabel 2 Keseluruhan Tanggapan Responden ditinjau dari Komponen Kualitas Interaksi (Interaction Quality)

\begin{tabular}{cccc}
\hline No & Indikator & Rata-rata Jawaban Responden & Peringkat Kualitas \\
\hline 1 & Sikap Petugas & 4,21 & 2 \\
2 & Perilaku Petugas & 4,17 & 3 \\
3 & Keahlian Petugas & 4,27 & 1 \\
\hline \multicolumn{2}{c}{ Jumlah } & 12,65 & \multirow{2}{*}{ Kategori Berkualitas } \\
\hline
\end{tabular}

Sumber: Hasil Olahan Data Primer, 2018 
Kualitas interaksi diukur berdasarkan hasil penilaian indikator sikap petugas, perilaku petugas dan keahlian petugas. Hasil pengolahan data menunjukkan bahwa sebagian besar responden memberikan penilaian positif pada komponen kualitas interaksi dengan nilai rata-rata 4,22. Hal tersebut memiliki makna bahwa responden memiliki kencenderungan mempersepsikan kualitas interaksi yang terselenggara di Puskesmas Tanasitolo ke dalam kategori berkualitas (rentang 4-<5).

\section{Kualitas Lingkungan Fisik (Physical Environment Quality)}

Kualitas lingkungan fisik (physical environment quality) adalah keberadaan lingkungan dan sekitarnya yang dapat memiliki pengaruh signifikan terhadap keseluruhan kualitas pelayanan kesehatan rawat jalan yang dirasakan oleh peserta BPJS Kesehatan yang terdapat di Puskesmas Tanasitolo, yang meliputi: kondisi ruangan, desain ruangan, dan faktor sosial. Adapun hasil penelitian dari komponen kualitas lingkungan fisik (physical environment quality) adalah sebagai berikut:

\section{a. Kondisi Ruangan}

Kondisi ruangan adalah suasana atau keadaaan di Puskesmas Tanasitolo baik kebersihan maupun temperatur ruangan sehingga pasien nyaman dalam mendapatkan pelayanan. Tanggapan responden tentang ruangan di puskesmas selalu terjaga kebersihannya diperoleh rata-rata jawaban responden adalah 4,06 dengan jumlah persentase jawaban sangat setuju dan setuju sebanyak $87,9 \%$. Hal ini menunjukkan bahwa ruangan di puskesmas selalu terjaga kebersihannya. Tanggapan responden tentang ruangan pemeriksaan pasien nyaman diperoleh rata-rata jawaban responden adalah 4,15 dengan jumlah persentase jawaban sangat setuju dan setuju sebanyak $92,9 \%$. Hal ini menunjukkan bahwa ruangan pemeriksaan pasien nyaman.

Tanggapan responden tentang sarana dan prasarana di puskesmas berada dalam kondisi baik untuk digunakan diperoleh rata-rata jawaban responden adalah 4,15 dengan jumlah persentase jawaban sangat setuju dan setuju sebanyak 96\%. Hal ini menunjukkan bahwa sarana dan prasarana di puskesmas berada dalam kondisi baik untuk digunakan.

\section{b. Desain Ruangan}

Desain ruangan adalah penataan atau fasilitas yang ada di lingkungan Puskesmas Tanasitolo yang bersifat fungsional. Tanggapan responden tentang penataan ruangan puskesmas sudah baik dalam mendukung pelayanan yang ada diperoleh rata-rata jawaban responden adalah 4,05 dengan jumlah persentase jawaban sangat setuju dan setuju sebanyak $93,9 \%$. Hal ini menunjukkan bahwa penataan ruangan puskesmas sudah baik dalam mendukung pelayanan yang ada. Tanggapan responden tentang pemilihan warna yang digunakan puskesmas diperoleh rata-rata jawaban responden adalah 4,12 dengan jumlah persentase jawaban sangat setuju dan setuju sebanyak 98\%. Hal ini menunjukkan bahwa responden menyukai pemilihan warna yang digunakan puskesmas. Tanggapan responden tentang tata letak peralatan kesehatan di puskesmas sudah sesuai pada tempatnya diperoleh rata-rata jawaban responden adalah 4,11 dengan jumlah persentase jawaban sangat setuju dan setuju sebanyak 96\%. Hal ini menunjukkan bahwa tata letak peralatan kesehatan di puskesmas sudah sesuai pada tempatnya.

\section{c. Faktor Sosial}

Faktor sosial adalah jumlah dan tipe orang yang berada dalam lingkungan Puskesmas Tanasitolo. Tanggapan responden tentang antrian pasien di puskesmas tidak padat diperoleh rata-rata jawaban responden adalah 3,56 jumlah persentase jawaban kurang setuju sebanyak 55,6\%. Hal ini menunjukkan bahwa antrian pasien di Puskesmas padat. Tanggapan responden tentang pasien selalu patuh antri sesuai dengan antriannya diperoleh rata-rata jawaban responden adalah 4,02 dengan jumlah persentase jawaban sangat setuju dan setuju sebanyak $84,9 \%$. Hal ini menunjukkan bahwa pasien selalu patuh antri sesuai dengan antriannya. Tanggapan responden tentang jumlah petugas yang ada di puskesmas sudah mencukupi diperoleh rata-rata jawaban responden adalah 4,14 dengan jumlah persentase jawaban sangat setuju dan setuju sebanyak 95\%. Hal ini menunjukkan bahwa jumlah petugas yang ada di puskesmas sudah mencukupi.

d. Kesimpulan Kualitas Lingkungan Fisik (Physical Environment Quality)

Tabel 3. Keseluruhan Tanggapan Responden ditinjau dari Komponen Kualitas Lingkungan Fisik (Physical Environment Quality)

\begin{tabular}{cccc}
\hline No & Indikator & Rata-rata Jawaban Responden & Peringkat Kualitas \\
\hline 1 & Kondisi Ruangan & 4,12 & 1 \\
2 & Desain Ruangan & 4,09 & 2 \\
3 & Faktor Sosial & 3,91 & 3 \\
\hline & Jumlah & 12,12 & \multirow{2}{*}{ Kategori Berkualitas } \\
\hline
\end{tabular}

Sumber: Hasil Olahan Data Primer, 2018 
Kualitas lingkungan fisik diukur berdasarkan hasil penilaian indikator kondisi ruangan, desain ruangan dan faktor sosial. Hasil pengolahan data menunjukkan bahwa sebagian besar responden memberikan penilaian positif pada komponen kualitas lingkungan fisik dengan nilai rata-rata 4,04. Hal tersebut memiliki makna bahwa responden memiliki kencenderungan mempersepsikan kualitas lingkungan fisik Puskesmas Tanasitolo ke dalam kategori berkualitas (rentang 4-<5).

\section{Kualitas Hasil (Outcome Quality)}

Kualitas hasil (outcome quality) adalah akumulasi dari kegiatan pelayanan yang optimal secara efisien dan efektif dalam memberikan pelayanan kesehatan rawat jalan kepada peserta BPJS kesehatan. Adapun hasil penelitian dari komponen kualitas hasil (outcome quality) adalah sebagai berikut:

a. Kesan

Kesan adalah pengalaman yang dirasakan pasien selama menerima pelayanan di Puskesmas Tanasitolo. Tanggapan responden tentang petugas di Puskesmas berusaha memberikan pelayanan yang terbaik bagi pasien diperoleh rata-rata jawaban responden adalah 4,24 dengan jumlah persentase jawaban sangat setuju dan setuju sebanyak 99\%. Hal ini menunjukkan bahwa petugas di Puskesmas berusaha memberikan pelayanan yang terbaik bagi pasien. Tanggapan responden tentang pelayanan yang didapatkan sudah sesuai dengan fasilitas dan pelayanan yang seharusnya diperoleh rata-rata jawaban responden adalah 4,20 dengan jumlah persentase jawaban sangat setuju dan setuju sebanyak 100\%. Hal ini menunjukkan bahwa pelayanan yang didapatkan sudah sesuai dengan fasilitas dan pelayanan yang seharusnya. Tanggapan responden tentang pengalaman yang baik selama mendapatkan pelayanan di Puskesmas diperoleh rata-rata jawaban responden adalah 4,21dengan jumlah persentase jawaban sangat setuju dan setuju sebanyak $100 \%$. Hal ini menunjukkan bahwa pengalaman yang baik selama mendapatkan pelayanan di Puskesmas.

b. Kesimpulan Kualitas Hasil (Outcome Quality)

Tabel 4. Keseluruhan Tanggapan Responden ditinjau dari Komponen Kualitas Hasil (Outcome Quality)

\begin{tabular}{cccc}
\hline No & Indikator & Rata-rata Jawaban Responden & Peringkat Kualitas \\
\hline 1 & Kesan & 4,22 & 1 \\
\hline & Jumlah & 4,22 & Kategori Baik \\
\hline
\end{tabular}

Sumber: Hasil Olahan Data Primer, 2018

Kualitas hasil diukur adalah waktu tunggu dan kesan. Hasil pengolahan data menunjukkan bahwa sebagian besar responden memberikan penilaian positif pada komponen kualitas hasil dengan nilai rata-rata 4,22. Hal tersebut memiliki makna bahwa responden memiliki kencenderungan mempersepsikan kualitas hasil Puskesmas Tanasitolo ke dalam kategori baik (rentang 4-<5).

\section{Pembahasan}

\section{Komponen Kualitas Interaksi (Interaction Quality)}

Menurut Brady and Cronin (2001), interaksi personal selama pemberian jasa sering memiliki pengaruh terbesar dalam persepsi kualitas jasa. Interaksi personal diartikan sebagai pertemuan antara petugas dan pelanggan. Menurut Kallenbach (2008) dalam Sari (2012), interaksi merupakan jantung dari pengalaman seorang pelanggan. Jika interaksi yang berlangsung berjalan dengan baik, hal tersebut tidak hanya akan membuat pelanggan puas, melainkan juga senang. Sebaliknya, jika interaksi berlangsung secara buruk, hal tersebut akan berujung pada frustasi. Menurut Gurses dalam Sari (2012), pengukuran tingkat situasi dapat menggambarkan beban kerja yang dialami petugas yang terkait dengan desain sistem pelayanan kesehatan tempat petugas tersebut bekerja. Dalam penelitiannya,ditemukan bahwa kebutuhan pasien yang banyak dan komunikasi yang tidak efektif mempengaruhi beban kerja level situasi. Menurut Lang TA, Hodge M., dan Olson V, et al. (2004) yang dikutip dalam Sari (2012), dimana beban kerja petugas yang berat memberikan pengaruh yang buruk pada keselamatan pasien (patient safety).

\section{Sikap Petugas}

Dalam penelitian ini terdapat keterbatasan dimana tidak dilakukannya pembedaan penilaian antara dokter, dokter gigi, perawat, bidan, apoteker, tenaga analisis dalam instrumen yang digunakan. Hal tersebut dikarenakan komponen penilaian pelayanan yang diambil didasarkan pada aspek umum yaitu petugas kesehatan yang melayani langsung pasien pada saat itu.

Dalam hal ini, penilaian indikator sikap petugas mencakup kepedulian petugas pada pasiennya, petugas yang tanggap, serta kesediaan petugas dalam mencarikan informasi. Secara umum, responden menilai bahwa sikap petugas yang menangani pasien di Puskesmas Tanasitolo tergolong berkualitas (rentang $4-<5$ ), dengan nilai rata-rata sebanyak 4,21. Hal tersebut memberikan penilaian yang positif mengenai sikap petugas. Didukung dengan 
wawancara yang dilakukan dari beberapa informan. Informan menyatakan petugas sangat peduli dengan kondisi pasien, ramah dan sudah sangat bagus serta sudah menerapkan prinsip 3S (Senyum, Sapa, Salam).

\section{Perilaku Petugas}

Secara umum, responden menilai bahwa perilaku petugas yang menangani pasien di Puskesmas Tanasitolo tergolong berkualitas (rentang 4-<5), dengan nilai rata-rata sebanyak 4,17. Hal tersebut memberikan penilaian yang positif mengenai perilaku petugas. Dalam hal ini, penilaian indikator perilaku petugas mencakup kecepatan petugas dalam merespon kebutuhan pasien, kesabaran dalam menjawab pertanyaan dan keluhan pasien dan kesegeraan dalam memberikan bantuan. Didukung dengan wawancara yang dilakukan dari beberapa informan. Informan menyatakan petugas langsung melayani pasien yang datang tanpa memandang kelas kepesertaan mereka, kebutuhan yang diminta pasien selalu diberikan oleh petugas dan merespon apa yang pasien keluhkan.

\section{Keahlian Petugas}

Secara umum, responden menilai bahwa keahlian petugas yang menangani pasien di Puskesmas Tanasitolo tergolong berkualitas (rentang 4-<5), dengan nilai rata-rata sebanyak 4,27. Hal tersebut memberikan penilaian yang positif mengenai keahlian petugas. Dalam hal ini, penilaian indikator keahlian petugas mencakup keahlian petugas dalam bidangnya, kesalahan dalam memberikan pelayanan dan kemampuan petugas dalam memberikan penjelasan dengan bahasa yang mudah dimengerti. Didukung dengan wawancara yang dilakukan dari beberapa informan. Informan menyatakan petugas sangat terampil dalam melakukan pemeriksaan, petugas sudah kompeten pada bidangnya dibuktikan dengan adanya Surat Tanda Registrasi (STR) serta terkait hasil observasi bahwa petugas melakukan tindakan sesuai dengan Standar Prosedur Operasional (SOP).

Komponen kualitas interaksi (interaction quality) yang mendapat nilai tertinggi adalah keahlian petugas dengan rata-rata jawaban responden setiap indikator adalah 4,27. Menurut responden petugas yang menangani adalah petugas yang ahli dalam bidangnya, petugas tidak pernah melakukan kesalahan dalam memberikan pelayanan dan petugas memberikan penjelasan dengan bahasa yang mudah dan dapat dimengerti oleh pasien.

\section{Kualitas Lingkungan Fisik (Physical Environment Quality)}

Menurut Brady and Cronin (2001), keberadaan lingkungan dan sekitarnya dapat memiliki pengaruh yang signifikan terhadap persepsi keseluruhan kualitas jasa yang dirasakan. Menurut Kotler (1993) dalam Sari (2012), lingkungan fisik merupakan komponen berwujud yang penting dari sebuah jasa yang dapat memberikan petunjuk pelanggan dan membentuk gambaran persepsi secara langsung pada pikiran pelanggan. Menurut Keaveney (1995) dalam Sari (2012), seorang pelanggan memiliki kecenderungan untuk beralih ke penyedia jasa yang lain karena mendapatkan ketidaknyamanan lingkungan. Menurut Eisman (1998) dalam Sari (2012) mengatakan bahwa warna merupakan komponen visual yang kuat dari suatu pengaturan fisik, terutama untuk pengaturan interior. Penelitian menunjukkan bahwa warna dapat mempengaruhi suasana hati dan emosi seseorang.

\section{Kondisi Ruangan}

Secara umum, responden menilai bahwa kondisi ruangan di Puskesmas Tanasitolo tergolong berkualitas (rentang 4-<5), dengan nilai rata-rata sebanyak 4,12. Hal tersebut memberikan penilaian yang positif mengenai kondisi ruangan. Dalam hal ini, penilaian indikator kebersihan ruangan, kenyamanan ruangan dan kondisi sarana prasarana. Didukung dengan wawancara yang dilakukan dari beberapa informan. Informan menyatakan ruangan pemeriksaanya sudah bagus dilengkapi dengan tirai, ruang pemeriksaan bersih dan nyaman.

\section{Desain Ruangan}

Secara umum, responden menilai bahwa desain ruangan di Puskesmas Tanasitolo tergolong berkualitas (rentang 4-<5), dengan nilai rata-rata sebanyak 4,09. Hal tersebut memberikan penilaian yang positif mengenai desain ruangan. Dalam hal ini, penilaian indikator penataan ruangan, pemilihan warna, kesesuaian penempatan peralatan kesehatan yang ada di Puskesmas Tanasitolo. Didukung dengan wawancara yang dilakukan dari beberapa informan. Informan menyatakan bahwa peralatan kesehatan sudah disediakan disetiap ruangan, ruangan pemeriksaannya sudah bersih dan nyaman serta penataan ruangannya sudah teratur.

\section{Faktor Sosial}

Secara umum, responden menilai bahwa faktor sosial di Puskesmas Tanasitolo tergolong cukup berkualitas (rentang 3-<4), dengan nilai rata-rata sebanyak 3,91. Dalam hal ini, penilaian indikator antrian pasien, kepatuhan antri dan kesesuaian jumlah petugas.

Komponen kualitas lingkungan fisik (physical environment quality) yang mendapat nilai tertinggi adalah kondisi ruangan dengan rata-rata jawaban responden setiap indikator adalah 4,12. Menurut responden ruangan pemeriksaan di Puskesmas Tanasitolo bersih, sudah nyaman serta sarana dan prasaranan Puskesmas berada dalam kondisi baik untuk digunakan.

\section{Kualitas Hasil (Outcome Quality)}

Menurut Brady and Cronin (2001), kualitas hasil adalah hasil dari proses pelayanan yang baik berupa produk atau jasa yang diperoleh pelanggan untuk menjadi evaluasi dan penentu persepsi terhadap kualitas pelayanan. Menurut Mc Alexander, Kaldenberg dan Koenig (1994) dalam Sari (2012), meyakini bahwa kualitas hasil yang dirasakan 
seorang pelanggan (pasien) menjadi determinan primer persepsi pasien terhadap kualitas jasa. Menurut Zeithaml, Parasuraman, dan Berry (1990) dalam Sari (2012) karena pada dasarnya jasa tidak berwujud, maka jasa lebih sering disampaikan sebagai suatu kinerja (performance) dan pengalaman (experiences). Jika masih terdapat responden yang memberikan penilaian negatif, hal tersebut mengarah pada dua kemungkinan, yaitu penyampaian pelayanan kesehatan yang belum maksimal atau adanya perbedaan persepsi antara orang yang satu dengan yang lain. Menurut Sureschedar et al., (2002) dalam Sari (2012), pada dasarnya pertimbangan seorang pasien dalam menentukan apakah ia mendapatkan pengalaman rawat yang baik atau tidak, dipengaruhi oleh pengalaman perjumpaan pasien tersebut dengan pihak penyelenggara pelayanan kesehatan itu sendiri, yang kemudian dapat berkembang menjadi dasar penentu kepuasan pasien.

Secara umum, responden menilai bahwa kesan di Puskesmas Tanasitolo tergolong baik (rentang $4-<5$ ), dengan nilai rata-rata sebanyak 4,22. Dalam hal ini, penilaian indikator kesan atas petugas yang berusaha memberikan pelayanan yang terbaik, kesan atas kesesuaian fasilitas pelayanan kesehatan dan kesan atas pengalaman selama mendapatkan pelayanan di Puskesmas Tanasitolo. Kesan responden terhadap petugas di Puskesmas yaitu petugas berusaha memberikan pelayanan yang terbaik bagi pasien dan pelayanan yang didapatkan sudah sesuai dengan fasilitas dan pelayanan yang seharusnya serta pengalaman yang baik selama mendapatkan pelayanan di puskesmas. Berdasarkan hasil penelitian kualitas pelayanan kesehatan peserta BPJS kesehatan di Puskesmas Tanasitolo Kabupaten Wajo yang ditinjau dari komponen kualitas interaksi (interaction quality), kualitas lingkungan fisik (physical environment quality), dan kualitas hasil (outcome quality). Penilaian kualitas interaksi (interaction quality) $(4,22)$ dan komponen kualitas hasil (outcome quality) $(4,22)$ memperoleh penilaian lebih baik dibanding komponen lingkungan fisik (physical environment quality) (4,04).

Secara keseluruhan hasil pengolahan data menunjukkan bahwa responden mempersepsikan kualitas pelayanan peserta BPJS kesehatan di Puskemas Tanasitolo tergolong berkualitas dan baik dimana komponen kualitas interaksi (interaction quality) dan kualitas hasil (outcome quality) dirasa paling baik dengan nilai rata-rata 4,22. Hasil penelitian ini sejalan dengan hasil penelitian yang dilakukan oleh Nurcahyanti dan Setiawan (2016) bahwa dimensi mutu interaksi (interaction quality) memiliki nilai mean 77 (kategori sangat baik), mutu lingkungan fisik (physical environment quality) memiliki nilai mean 75 (kategori baik) dan mutu hasil (outcome quality) memiliki nilai mean 76 (kategori sangat baik). Artinya, responden menilai paling tinggi pada dimensi mutu interaksi (interaction quality) dibanding dengan mutu lingkungan fisik (physical environment quality). Hasil penelitian lain yang sejalan dilakukan oleh Wirdiyanto (2008) bahwa hasil penelitian menunjukkan mean harapan pasien (importance) menurut dimensi kualitas interaksi adalah 3,6, lingkungan fisik adalah 3,51 dan hasil adalah 3,56. Mean penilaian pasien (performance) menurut dimensi kualitas interaksi adalah 3,36, lingkungan fisik adalah 3,25 dan hasil adalah 3,24. Dimana dapat dilihat bahwa dimensi kualitas interaksi memiliki penilaian tertinggi.

\section{Gambaran Kualitas Pelayanan Kesehatan Peserta BPJS Kesehatan}

Hasil penilaian kualitas pelayanan kesehatan peserta BPJS kesehatan di Puskesmas Tanasitolo Kabupaten Wajo yang ditinjau dari komponen kualitas interaksi (interaction quality), kualitas lingkungan fisik (physical environment quality), dan kualitas hasil (outcome quality). Penilaian kualitas interaksi (interaction quality) $(4,22)$ dan kualitas hasil (outcome quality) $(4,22)$ memperoleh penilaian lebih baik dibanding komponen lingkungan fisik (physical environment quality) (4,04). Secara keseluruhan hasil pengolahan data menunjukkan bahwa responden mempersepsikan kualitas pelayanan peserta BPJS kesehatan di Puskemas Tanasitolo tergolong berkualitas dan baik dimana komponen kualitas interaksi (interaction quality) dan kualitas hasil (outcome quality) dirasa paling baik dengan nilai rata-rata 4,22. Hasil penelitian ini sejalan dengan hasil penelitian yang dilakukan oleh Nurcahyanti dan Setiawan (2016) bahwa dimensi mutu interaksi (interaction quality) memiliki nilai mean 77 (kategori sangat baik), mutu lingkungan fisik (physical environment quality) memiliki nilai mean 75 (kategori baik) dan mutu hasil (outcome quality) memiliki nilai mean 76 (kategori sangat baik). Artinya, responden menilai paling tinggi pada dimensi mutu interaksi (interaction quality) dibanding dengan mutu lingkungan fisik (physical environment quality).

Hasil penelitian sejalan dengan teori yang sama dilakukan oleh Sari (2012) bahwa dimensi mutu interaksi (interaction quality) dirasa paling baik oleh responden di unit rawat inap B dan C Rumah Sakit Bhayangkara Tingkat I Raden Said Sukanto. Hasil penelitian lain yang sejalan dilakukan oleh Wirdiyanto (2008) bahwa hasil penelitian menunjukkan mean harapan pasien (importance) menurut dimensi kualitas interaksi adalah 3,6, lingkungan fisik adalah 3,51 dan hasil adalah 3,56. Mean penilaian pasien (performance) menurut dimensi kualitas interaksi adalah 3,36, lingkungan fisik adalah 3,25 dan hasil adalah 3,24. Dimana dapat dilihat bahwa dimensi kualitas interaksi memiliki penilaian tertinggi.

\section{Kesimpulan}

Kualitas pelayanan kesehatan peserta BPJS kesehatan di Puskesmas Tanasitolo Kabupaten Wajo pada komponen kualitas interaksi (interaction quality) dan lingkungan fisik (physical environment quality) tergolong dalam kategori berkualitas, sementara kualitas hasil (outcome quality) tergolong dalam kategori baik. 


\section{Saran}

Untuk mengoptimalkan pelayanan kesehatan peserta BPJS kesehatan maka manajemen Puskesmas perlu meningkatkan kemampuan teknis petugas kesehatan untuk mengurangi kemungkinan terjadinya kesalahan dalam memberikan pelayanan kepada pasien, kemampuan komunikasi inter-personal, baik kepada rekan kerja maupun kepada pasien untuk menunjang penyelenggaraan pelayanan prima. Meningkatkan upaya pembangunan dan pemeliharaan fasilitas fisik baik dari segi perencanaan pengadaan, perawatan fungsi dan kebersihannya, serta meningkatkan kepatuhan antrian pasien untuk mencegah pasien beralih ke penyedia pelayanan yang lain karena mendapatkan ketidaknyamanan. Melakukan penilaian dan pembenahan secara terus-menerus untuk mencapai tingkat kepuasan yang memenuhi harapan pasien. Untuk menjaga kualitas pelayanan kesehatan pasien di Puskesmas Tanasitolo perlu membentuk tim kendali mutu yang berfungsi menilai, menjaga, memperbaiki, dan meningkatkan kualitas pelayanan kesehatan secara berkelanjutan.

\section{Referensi}

PJS Kesehatan. Jumlah Faskes dan Peserta, Diakses pada tanggal 25 November 2017, jam 19.59 WITA, http://bpjskesehatan.go.id/bpjs/index.php/jumahPeserta

BPJS Kesehatan. 470 Kabupaten/Kota telah Intergrasikan Jamkesda ke JKN-KIS, Diakses pada tanggal 23 November 2017, jam 21.23 WITA, www.bpjs-kesehatan.go.id

Brady and Cronin. 2001. "Some New Thoughts on Conceptualizing Perceived Service Quality: A Hierarchical Approach”. Journal of Marketing, vol.63, no.3 July 2001:34-39.

Fitria, M. et.al. 2014. “Analysis of Service Quality According Brady and Cronin Concept in Pediatrics Clinic”. Jurnal Administrasi Kesehatan Indonesia, vol. 2, no. 1 Januari-Maret 2014

Kementerian Kesehatan Republik Indonesia. 2013. Buku Pengangan Sosialisasi Jaminan Kesehatan Nasional (JKN) dalam Sistem Jaminan Sosial Nasional.

Nurcahyanti dan Setiawan. 2016. "Studi Hubungan Antara Mutu Pelayanan Kesehatan dengan Kepuasan Pasien di Unit Pelayanan Rawat Inap Rumah Sakit Umum Daerah Bhakti Dharma Husada Kota Surabaya”. Jurnal Manajemen Kesehatan, vol. 3 no. 1 April 2017:15-30.

Nursalam. 2008. Konsep dan Penerapan Metodologi Penelitian Ilmu Keperawatan. Surabaya: Salemba Medika.

Riyadi, R. 2015. Mutu Pelayanan Kesehatan Peserta Jaminan Kesehatan Nasional di Puskesmas Kecamatan Kembangan Jakarta Barat. Skripsi Jakarta Barat: Universitas Islam Negeri Jakarta.

Sari. 2012. Studi Kualitas Jasa Instalasi Rawat Inap B dan C Rumah Sakit Bhayangkara Tingkat I Raden Said Sukanto. Skripsi. Depok: Universitas Indonesia.

Sugiyono. 2003. Metode Penelitian Administrasi. Bandung: Alfabeta.

Republik Indonesia. Undang-Undang No. 24 Tahun 2011 tentang BPJS

Republik Indonesia. Undang-Undang No.36 Tahun 2009 tentang Kesehatan

Republik Indonesia. Undang-Undang No. 40 Tahun 2004 tentang Sistem Jaminan Sosial Nasional (SJSN)

Wirdiyanto, W. 2008. Analisis Kepuasan Pasien Berdasarkan Importance-Performance Analysis dengan Menggunakan Dimensi Kualitas Jasa Brady dan Cronin (Studi di Klinik Spesialis Terpadu RSGMP FKG UNAIR). Skripsi. Surabaya: Universitas Airlangga Surabaya 